\title{
Development and evaluation of mosapride citrate orally disintegrating tablets for dogs
}

\author{
Desenvolvimento e avaliação de comprimidos de desintegrados \\ de citrato demosaprida para cães por via oral
}

\author{
Tingting $\mathbf{Y i}^{\mathrm{I}}$,II
}

\section{ABSTRACT}

The purpose of the study was to prepare orally disintegrating tablets (ODTs) of mosapride citrate for dogs with fast disintegration and low cost. The ODTs were developed by varying the components and the ratio of excipients. A direct compression method was used. The properties of the ODTs, including hardness, friability, active ingredient content, and in vitro disintegration time, were investigated, and an economic analysis of the formulations was performed. For all formulations, friability was less than $1 \%$, and the hardness varied from $37.69 \pm 4.08$ to $48.73 \pm 5.62$ $N$, which indicated that the tablets had sufficient mechanical integrity to withstand packaging and carrying. Results showed that Formulation $(F)$ 2, containing 5\% sodium carboxymethyl starch; F3, containing 5\% low-substituted hydroxypropylcellulose; and F5 had not only shorter disintegration times but also lower costs, which were suitable for mosapride citrate ODTs. Although F1, contained $5 \%$ croscarmellose sodium, and F4, contained 5\% crospovidone, with shorter disintegration times, the costs of F1 and F4 were $25.8 \%$ and $22.6 \%$ higher than that of $F 5$, respectively. Results also revealed that the disintegration time of $F 5$ was not significantly different from those of $F 1, F 2, F 3$, and F4 ( $p>0.05$ ), all of which contained superdisintegrants. Without superdisintegrants, F5, which contained a mixture of microcrystalline cellulose, mannitol, and lactose, was also able to achieve a short disintegration time and to meet the requirements of ODTs for dogs.

Key words: orally disintegrating tablets, disintegration time, mosapride citrate, dogs, superdisintegrant.

\section{RESUMO}

O objetivo do estudo foi o de preparar os comprimidos por via oral de desintegração (ODTs) de citrato de mosaprida para cães com desintegração rápida e de baixo custo. Os ODTs foram desenvolvidos através da variação dos componentes e proporção de excipientes. Um método de compressão direta foi utilizado. As propriedades dos ODTs, incluindo dureza, friabilidade, o teor de ingrediente ativo e no tempo de desintegração in vitro foram investigados e, adicionalmente, uma análise econômica das formulações foi realizada. Para todas as formulações, friabilidade foi inferior a 1\%, a dureza e variou de 37,69 $\pm 4,08-48,73 \pm 5,62$ $N$, o que indica que os comprimidos tinham integridade mecânica suficiente para suportar a embalagem e transporte. Os resultados mostraram que a formulação $(F) 2$, contendo $5 \%$ de amido de carboximetilo de sódio, F3, contendo 5\% de hidroxipropil celulose de baixa substituição, e F5 não só tiveram menores tempos de desintegração mas também preços mais baixos, que foram adequados para ODTs de citrato de mosapride. Embora $F 1$, continha $5 \%$ de croscarmelose de sódio, e F4, continha 5\% de crospovidona, com tempos de desintegração mais curtos, os custos de F1 e F4 eram 25,8\% e 22,6\% mais elevado do que a F5, respectivamente.. Os resultados também revelam que o tempo de desintegração de F5 não foi significativamente diferente do de F1, F2, F3, e F4 (P> 0.05), todas as quais contêm superdesintegrantes. Sem superdesintegrantes, F5, que contêm uma mistura de celulose microcristalina, manitol e lactose também foi capaz de conseguir um curto tempo de desintegração e satisfaz os requisitos de ODTs para cães.

Palavras-chave: pastilhas de desintegração oral, tempo de desintegração, citrato de mosapride, cães, superdesintegrante.

\section{INTRODUCTION}

Oral medication is convenient, desirable for better compliance and relatively inexpensive for the treatment of animal disease. Compressed tablets are less popular for dogs because administration may be time consuming, hazardous and uncertain

'Department of pharmaceutical engineering No.70 Mail box, Qingdao University of Science \& Technology, No.53, Zhengzhou Road, Shibei District, Qingdao, Shandong Province China Qingdao, 266042, China. E-mail: yitingting_0@163.com. Corresponding author.

IIDepartment of Veterinary Medicine, Faculty of Technology and Animal Science, University of Agricultural Shandong, Taian, Shandong, China. 
(RAMTEKE et al., 2014). Flavoured chewable tablets are accepted voluntarily by dogs (RAMTEKE et al., 2014). However, some old or sick dogs cannot chew. All of these shortcomings can be overcome by the use of orally disintegrating tablets for dogs.

Orally disintegrating tablets (ODTs) are defined by the United States Food and Drug Administration (FDA) as "a solid dosage form containing medicinal substances which disintegrates rapidly, usually within a matter of seconds, when placed upon the tongue" (GUIDANCE FOR INDUSTRY 2008 DECEMBER). One of the greatest advantages of ODTs for dogs is the ability to ensure complete dosing by reducing medicine rejection with a convenient and safe method. After administering the medicine in dogs' mouths, ODTs will disintegrate quickly upon contact with saliva. To ensure the dispersion of the medicine, it is recommended that the dogs' mouths be kept closed for several seconds after dosing. It is therefore difficult to spit out, allowing the contents to be swallowed. In contrast, compressed tablets must be placed at the root of the tongue in order to avoid being spit out (RAMTEKE et al., 2014). Because ODTs can be easily administered to dogs, they can enhance the dogs' cooperation and treatment compliance. In addition, HIRANI et al. (2009) indicated that drug absorption, onset of action and bioavailability may be significantly improved as a result of the fast disintegration of ODTs. Furthermore, ODTs can be taken by dogs that cannot chew or feed because of age or sickness.

Many scientific methods, such as direct compression, wet granulation, moulding, spraydrying, freeze-drying, sublimation and some other patented techniques can be used to produce ODTs (BANDARI et al., 2008; BADGUJAR \& MUNDADA, 2011). Direct compression is the most convenient and economical method because no special equipment or other manufacturing process is required (BI et al., 1999; SWAMY et al., 2008).

Mosapride citrate is a new prokinetic medicine. It has been approved and marketed for human use since 1998 and for veterinary use since 2009 in Japan. TSUKAMOTO et al. $(2011 ; 2012)$ reported that mosapride citrate is effective in the improvement of anorexia and vomiting for dogs with hypomotility of the upper gastrointestinal tract (stomach and duodenum). The medicine selectively stimulates 5-HT4 receptors in the gastrointestinal nerve plexus and promotes the release of acetylcholine, thereby accelerating gastrointestinal motility and gastric emptying. Unlike other gastro-prokinetic agents, mosapride citrate has no affinity for the dopamine D2 receptor, which causes central nervous system and endocrine-related adverse reactions (TSUKAMOTO et al., 2011; TSUKAMOTO et al., 2012).

In the present study, new formulations were developed as ODTs containing mosapride citrate. Two issues were considered in their development. One was the achievement of fast disintegration and rapid onset, which are very important for ODTs. The other was low cost, which would make the formulations more affordable for veterinary use, particularly in developing countries.

\section{MATERIALS AND METHODS}

\section{Materials}

Mosapride citrate was kindly donated by Lunan New Time Bio-Tech Co., LTD (Lunan, China). Microcrystalline cellulose (MCC) (WJ102), pregelatinized starch, colloidal silicon dioxide, magnesium stearate, croscarmellose sodium $(\mathrm{CCNa})$, low-substituted hydroxypropylcellulose (L-HPC), crospovidone (PVPP) (SL-10), and sodium carboxymethyl starch (CMS-Na) were donated by Anhui Shanher Pharmaceutical Excipient Co., LTD (Anhui, China). Mannitol was a gift from Bright Moon Seaweed Group (Qingdao, China). Lactose was kindly donated by Shanxi Huaqi Medicinal Materials Co., LTD (Shanxi, China). The HPLC solvents methanol, triethylamine and glacial acetic acid were chromatographic grade and purchased from Sinopharm Chemical Reagent Co., LTD (Shanghai, China). All materials were used as received.

Preparation of formulations

MCC, mannitol, lactose, and pregelatinized starch were used as the basic excipients. Magnesium stearate was added as a lubricant. CCNa, L-HPC, PVPP and CMS-Na were selected as superdisintegrants. All excipients and mosapride citrate were weighed according to the specific formulation and mixed thoroughly for $10 \mathrm{~min}$ with a roller mixer. Then, blends were directly compressed in a Tianxiang \& Chentai rotary tablet press (Shanghai, China) using 10 -mm normal flat punches. The ODT formulations developed for mosapride citrate and their contents are given in table 1. Except for the superdisintegrant used, F1, F2, F3 and F4 have the same components, including $1 \%$ mosapride citrate, $35 \%$ MCC, $28.5 \%$ mannitol, $28.5 \%$ lactose and $2 \%$ magnesium stearate. Superdisintegrants in F1, F2, F3 and F4 were 5\% CCNa, 5\% CMS-Na, 5\% L-HPC, and 5\% PVPP, respectively. F5 contained $1 \%$ mosapride citrate, $35 \%$ MCC, $31 \%$ mannitol, $31 \%$ lactose and $2 \%$ 
Table 1 - Compositions of the mosapride citrate ODT formulations. $\mathrm{F}=$ formulation. $\mathrm{MCC}=$ microcrystalline cellulose, $\mathrm{CCNa}=\mathrm{croscarmellose}$ sodium, CMS-Na=sodium carboxymethyl starch, L-HPC=low-substituted hydroxypropylcellulose, $\mathrm{PVPP}=$ crospovidone.

\begin{tabular}{|c|c|c|c|c|c|c|c|}
\hline Ingredients (\%) & $\mathrm{F} 1$ & $\mathrm{~F} 2$ & $\mathrm{~F} 3$ & $\mathrm{~F} 4$ & F5 & F6 & F7 \\
\hline Mosapride citrate & 1 & 1 & 1 & 1 & 1 & 1 & 1 \\
\hline $\mathrm{MCC}$ & 35 & 35 & 35 & 35 & 35 & 35 & 25 \\
\hline Mannitol & 28.5 & 28.5 & 28.5 & 28.5 & 31 & - & 36 \\
\hline Lactose & 28.5 & 28.5 & 28.5 & 28.5 & 31 & 31 & 36 \\
\hline Pregelatinized starch & - & - & - & - & - & 31 & - \\
\hline $\mathrm{CCNa}$ & 5 & - & - & - & - & - & 一 \\
\hline $\mathrm{CMS}-\mathrm{Na}$ & - & 5 & - & - & - & - & - \\
\hline L-HPC & - & - & 5 & - & - & - & - \\
\hline PVPP & - & - & - & 5 & - & - & 一 \\
\hline Magnesium stearate & 2 & 2 & 2 & 2 & 2 & 2 & 2 \\
\hline
\end{tabular}

magnesium stearate. F6 contained $1 \%$ mosapride citrate, $35 \%$ MCC, $31 \%$ lactose, $31 \%$ pregelatinized starch and $2 \%$ magnesium stearate. F7 contained $1 \%$ mosapride citrate, $25 \%$ MCC, $36 \%$ mannitol, $36 \%$ lactose and $2 \%$ magnesium stearate.

Evaluation of tablets

Various aspects, including thickness, diameter, weight, hardness, friability, disintegration time and drug content, were investigated. All these tests were conducted according to the Chinese Pharmacopeia 2010 and should meet their requirements. The mean \pm standard deviation (SD) is reported.

Uniformity of mass - Twenty tablets were randomly selected and individually weighed using a Mettler Toledo digital balance (model EL204, Shanghai, China).

Tablet hardness - A YD-20 hardness tester (Tianjin University Wireless power plant, Tianjin, China) was used to evaluate the tablet hardness by measuring the breaking strength in the radial direction. Ten tablets of each formulation were randomly selected and measured.

Friability - The friability of the tablets was evaluated by a Friabilator (model CS-2, Tianjin Optical Instrument Factory, Tianjin, China). Ten preweighed tablets were rotated at $25 \mathrm{rpm} / \mathrm{min}$ for $4 \mathrm{~min}$ in a plastic chamber. Tablets were then dusted and reweighed, and the friability was calculated.

In vitro disintegration time - Disintegration tests were performed using a Guoming disintegration tester (model BJ-1, Tianjin, China). Six tablets of each formulation were chosen at random and individually placed into the basket vibrating at a rate of $30 \pm 2$ cycles $/ \mathrm{min}$. The testing medium was distilled water $(900 \mathrm{ml})$ at $37 \pm 1^{\circ} \mathrm{C}$. Disintegration time was recorded as the time at which the tablet disintegrated and passed completely through the screen.
Drug content assay - The drug content was determined by HPLC according to the Chinese Pharmacopeia 2010. A new, inexpensive mobile phase was developed.

Chromatographic conditions - A Kromasil column (PC-1025, 250×4.6mm; Guangzhou FLM Scientific Instrument Co., Ltd) was used and packed with $\mathrm{C} 18(5 \mu \mathrm{m})$. The mobile phase was a solution of HPLC-grade methanol, water, glacial acetic acid and triethylamine at a ratio of 1600:400:05:1 (RAO et al., 2004) which was injected into the system at a flow rate of $0.8 \mathrm{ml} / \mathrm{min}$ after being filtered through a $0.45 \mu \mathrm{m}$ membrane filter. The column temperature was kept at $30^{\circ} \mathrm{C}$, and the spectrophotometer was set to a detection wavelength of $274 \mathrm{~nm}$. The sample injection volume was $20 \mu$ l. The test was considered invalid unless the column efficiency was not less than 1500 theoretical plates, the tailing factor was not more than 2.0, and the relative standard deviation for replicate injections was not more than 2.0 percent.

Test solution - Twenty tablets were weighed and powdered. A quantity of the powder containing approximately $5 \mathrm{mg}$ of mosapride citrate was accurately weighed and transferred into a $100 \mathrm{ml}$ volumetric flask. The powder was dissolved in the mobile phase to $80 \mathrm{ml}$ and sonicated for 10 minutes. Then, the mobile phase was added to a final volume of $100 \mathrm{ml}$, and the solution was filtered through $0.45 \mu \mathrm{m}$ membrane filter.

Reference solution, Procedure, Statistical analysis - Approximately 5mg of the mosapride citrate reference substance was accurately weighed, and the same procedure used for the test solution was followed for the reference solution. Test solution and reference solution were injected separately. Drug content was calculated by an external standard method based the peak area. All data were analysed with SPSS 
20.0 for Windows. A one-way analysis of variance was used. The significant level was set at 0.05 .

\section{RESULTS}

Evaluation of tablet characteristics

The tablet characteristics of the mosapride citrate ODTs formulation are given in table 2 . Diameter and thickness of the formulations were almost the same. Weight variation was less than $5 \%$ and met the requirements for ODTs. Hardness varied from $37.69 \pm 4.08$ to $48.73 \pm 5.62 \mathrm{~N}$, and the friability was less than $1 \%$, indicating that the tablets had sufficient mechanical integrity and would be able to withstand packaging and carrying.

In vitro disintegration time

The disintegration times were $26.33 \pm 2.34 \mathrm{~s}$ for F1, containing 5\% CCNa; 22.33 \pm 2.07 s for F2, containing 5\% CMS-Na; $21.17 \pm 1.33$ s for F3, containing 5\% L-HPC; $20.83 \pm 1.94$ s for F4, containing 5\% PVPP; $22.67 \pm 2.34 \mathrm{~s}$ for F5; $221 \pm 17$ s for F6; and $34.83 \pm 2.79$ s for F7, with significant differences among the formulations $(p<0.05)$.

\section{Economic analysis of formulations}

The price of each component sold by four major companies in the market, such as Anhui Shanher Pharmaceutical Excipient Co., LTD, Shanxi Huaqi Medicinal Materials Co., LTD, Hunan ErKang Pharmaceutical Co., LTD, and Xian TianZheng Pharmaceutical Excipient Co., LTD, was determined in September 2015. Four prices of each component were averaged to find the average price of each component in Chinese yuan. Based on the average price of each component, the total cost of each formulation (F1-F5) was calculated in Chinese yuan. The total costs of F6 and F7 were not calculated because of their long disintegration times. According to the conversion of 1 U.S. dollar to 6.2284 yuan, which was the average exchange rate in 2015 , the average price of each component and the total cost of each formulation (F1-F5) were converted into dollars. The average price of each component is shown in table 3. The total cost of each formulation (F1-F5) is shown in figure 1.

\section{DISCUSSION AND CONCLUSIONS}

Disintegration time of F5 was not significantly different from those of F1, F2, F3, and F4 ( $>00.05$ ). F1, F2, F3 and F4 each contained a type of superdisintegrant. Superdisintegrants, including CCNa, L-HPC, PVPP, and CMS-Na, are commonly used in ODTs for fast disintegration. F5 did not contain superdisintegrants, and the portion of the formulation corresponding to the superdisintegrants was made up by MCC. Without the presence of superdisintegrants, the rapid disintegration of F5 was mainly because of the MCC (LERK et al., 1979; JIVRAJ et al., 2000). MCC can act as a multifunctional excipient and is widely used in ODTs (DOUROUMIS et al., 2011; OLMEZ et al., 2013). When compressed, MCC plastically deforms (WESTERMARCK et al., 1999). The strength of MCC tablets is attributed to hydrogen bonds generated during plastic deformation. Thus, tablets that are satisfactory in terms of hardness and friability can be obtained. Once in contact with water, the tablets swell and disintegrate quickly. This process is the result of the penetration of water into the cellulose matrix because of pore capillary action, followed by the

Table 2 - Physical properties of tablets. $\mathrm{F}=$ formulation. Except for the superdisintegrants, F1, F2, F3 and F4 have the same components, including $1 \%$ mosapride citrate, $35 \%$ microcrystalline cellulose, $28.5 \%$ mannitol, $28.5 \%$ lactose and $2 \%$ magnesium stearate. The superdisintegrants of F1, F2, F3 and F4 were 5\% CCNa, 5\% CMS-Na, 5\% L-HPC, and 5\% PVPP, respectively. F5 contained 1\% mosapride citrate, $35 \%$ microcrystalline cellulose, $31 \%$ mannitol, $31 \%$ lactose and 2\% magnesium stearate. F6 contained $1 \%$ mosapride citrate, 35\% microcrystalline cellulose, 31\% lactose, 31\% pregelatinized starch and $2 \%$ magnesium stearate. F7 contained $1 \%$ mosapride citrate, $25 \%$ microcrystalline cellulose, $36 \%$ mannitol, $36 \%$ lactose and $2 \%$ magnesium stearate. $\mathrm{N}=$ Newton, $\mathrm{S}=$ second.

\begin{tabular}{|c|c|c|c|c|c|c|c|}
\hline & $\mathrm{F} 1$ & F 2 & F 3 & F 4 & F 5 & F 6 & F 7 \\
\hline$\overline{\operatorname{Hardness}(\mathrm{N})^{\mathrm{a}}}$ & $44.23 \pm 5.54$ & $39.26 \pm 4.13$ & $48.73 \pm 5.62$ & $42.37 \pm 3.75$ & $37.69 \pm 4.08$ & $39.09 \pm 2.74$ & $46.48 \pm 3.67$ \\
\hline Friability $(\%)^{\mathrm{a}}$ & 0.71 & 0.82 & 0.87 & 0.98 & 0.88 & 0.85 & 0.79 \\
\hline Disintegration time $(\mathrm{S})^{\mathrm{b}}$ & $26.33 \pm 2.34$ & $22.33 \pm 2.07$ & $21.17 \pm 1.33$ & $20.83 \pm 1.94$ & $22.67 \pm 2.34$ & $221 \pm 17$ & $34.83 \pm 2.79$ \\
\hline Weight $(\mathrm{mg})^{\mathrm{c}}$ & $505 \pm 19$ & $493 \pm 21$ & $487 \pm 26$ & $510 \pm 31$ & $496 \pm 19$ & $516 \pm 09$ & $502 \pm 33$ \\
\hline $\operatorname{Diameter}(\mathrm{mm})^{\mathrm{a}}$ & $12.10 \pm 0$ & $12.10 \pm 0$ & $12.10 \pm 0$ & $12.10 \pm 0$ & $12.10 \pm 0$ & $12.10 \pm 0$ & $12.10 \pm 0$ \\
\hline Thickness $(\mathrm{mm})^{\mathrm{a}}$ & $4.05 \pm 0.02$ & $3.98 \pm 0.07$ & $4.03 \pm 0.03$ & $3.99 \pm 0.06$ & $4.01 \pm 0.02$ & $4.02 \pm 0.04$ & $3.98 \pm 0.05$ \\
\hline Drug content $^{\mathrm{d}}$ & $98.24 \pm 0.13$ & $97.92 \pm 0.49$ & $98.41 \pm 0.08$ & $98.22 \pm 0.25$ & $98.31 \pm 0.09$ & $97.69 \pm 0.35$ & $97.98 \pm 0.41$ \\
\hline
\end{tabular}

Note: ${ }^{\mathrm{a}} \mathrm{n}=10 .{ }^{\mathrm{b}}$ In vitro disintegration time, $\mathrm{n}=6 .{ }^{\mathrm{c}} \mathrm{n}=20 .{ }^{\mathrm{d}} \mathrm{n}=3$. 
Table 3 - Average prices in September 2015 of each component used in the study. $\mathrm{MCC}=$ microcrystalline cellulose, $\mathrm{CCNa}=$ croscarmellose sodium, $\mathrm{CMS}-\mathrm{Na}=$ sodium carboxymethyl starch, L-HPC=low-substituted hydroxypropylcellulose, $\mathrm{PVPP}=$ crospovidone.

\begin{tabular}{lll}
\hline Sequence number & excipient & average price $(\$ / \mathrm{kg})$ \\
\hline 1 & MCC & 2.89 \\
2 & Mannitol & 6.42 \\
3 & Lactose & 3.69 \\
4 & CCNa & 26.81 \\
5 & CMS-Na & 3.69 \\
6 & L-HPC & 7.22 \\
7 & PVPP & 24.08 \\
8 & Magnesium stearate & 3.21 \\
\hline
\end{tabular}

disruption of the hydrogen bonds (LERK et al., 1979). In addition, MCC shows good flow characteristics due to porosity and is suitable for direct compression.

F7 and F5 disintegrated at $34.83 \pm 2.79 \mathrm{~s}$ and $22.67 \pm 2.34 \mathrm{~s}$, respectively. This difference in disintegration time was significant $(p<0.05)$. The disintegration time of F7 was significantly different from those of F1, F2, F3, and F4 $(p<0.05)$. Without superdisintegrants, when the concentration of MCC was decreased from $35 \%$ (F5) to $25 \%$ (F7), the disintegration time increased and was significantly different $(\mathrm{p}<0.05)$ from those of the formulations containing superdisintegrants. In general, the proportion of MCC in ODTs used for human is low because MCC does not dissolve in water and can cause a feeling of grittiness in the mouth. However, dogs are not sensitive to grittiness. For dogs, higher concentrations of MCC could improve the rapid disintegration of ODTs, and accordingly, F5 was better than F7 because of its shorter disintegration time.

Prices of mannitol and pregelatinized starch were 6.42 and 1.93 dollars $/ \mathrm{kg}$, respectively. In order to reduce the cost of the formulation, F6 used a pregelatinized starch replacement for the mannitol in $\mathrm{F} 5$, and the cost of F6 was $33.1 \%$ lower than that of F5. $\mathrm{F} 5$ and $\mathrm{F} 6$ disintegrated at $22.67 \pm 2.34 \mathrm{~s}$ and $221 \pm 17 \mathrm{~s}$, respectively. This difference in disintegration time was significant $(\mathrm{p}<0.05)$. Just as reported in many cases, the presence of water-soluble diluents can facilitate tablet disintegration (LERK et al., 1979; OLMEZ et al., 2013). Although pregelatinized starch is a type of multifunctional excipient and is suitable for direct compression of powder, it is water-insoluble. In F6, the proportion of water-insoluble excipients was too high to meet the required disintegration time.

The costs of F2, F3, and F5 were 4.14, 4.32, and 4.21 dollars $/ \mathrm{kg}$, respectively. Considering

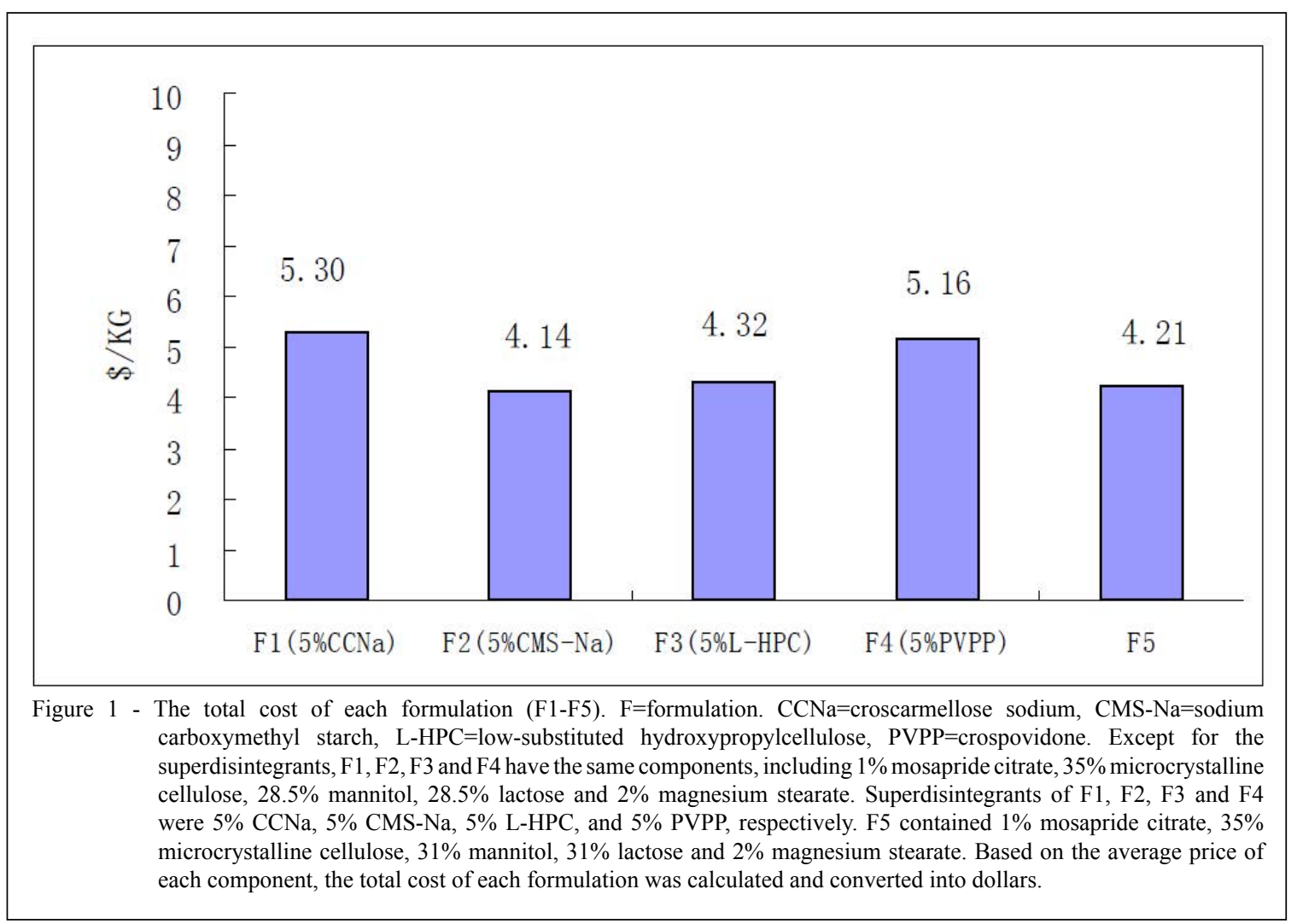

Ciência Rural, v.46, n.11, nov, 2016. 
price fluctuations, the costs of F2, F3, and F5 were nearly equivalent. The costs of F1 and F4 were $25.8 \%$ and $22.6 \%$ higher than that of $\mathrm{F} 5$, respectively. Contrast analysis indicated that the benefits of F2, F3, and F5 were prominent in terms of their low costs, which is especially important for drugs meant for pets.Although therapy for pets is not usually as cost-sensitive as that for livestock, expenses are also a problem for pet owners faced with a high price of medicine. Additionally, pharmaceutical industries need to profit in a competitive business environment, so low cost is an advantage in the development of veterinary ODTs (AHMED et al., 2002).

Results of this study indicated that F2, F3, and F5 had lower costs and shorter disintegration times. The disintegration times of F2, F3, and F5 were not significantly different ( $\mathrm{p}>0.05$ ). Therefore, F2, F3, and F5 are suitable for ODTs of mosapride citrate for dogs. The results also revealed that the disintegration time of F5 was not significantly different from those of F1, F2, F3, and F4 ( $>>0.05)$, all of which contained superdisintegrants. Without superdisintegrants, F5, which contained a mixture of MCC, mannitol, and lactose, could also achieve a short disintegration time and meet the requirements of ODTs for dogs.

\section{REFERENCES}

AHMED, I.; KASRAIAN, K. Pharmaceutical challenges in veterinary product development. Advanced Drug Delivery Reviews, v.54, n.6, p.871-882, 2002. Available from: <http://www. sciencedirect.com/science/article/pii/S0169409X02000741>. Accessed: Mar. 23, 2016. doi: 10.1016/S0169-409X(02)00074-1.

BADGUJAR, BP.; MUNDADA,AS. The technologies used for developing orally disintegrating tablets: A review. Acta Pharmaceutica, v.61, n.2, p.117-139, 2011. Available from: <http://dx.doi.org/10.2478/v10007-0110020-8>. Accessed: Jan. 14, 2015. doi: 10.2478/v10007-011-0020-8

BANDARI, S. et al. Orodispersible tablets: an overview. Asian Journal of Pharmaceutics, v.2, n.1, p.2-11, 2008. Available from: <https:// www.researchgate.net/pblication/26525567_Orodispersible_tablets_An _overview>. Accessed: Jan. 10, 2015. doi: 10.4103/0973-8398.41557.

BI, YX. et al. Evaluation of rapidly disintegrating tablets prepared by a direct compression method. Drug Development and Industrial Pharmacy, v.25, n.5, p.571-581, 1999. Available from: $<\mathrm{http} / / / \mathrm{dx}$. doi.org/10.1081/DDC100102211>. Accessed: Aug. 10, 2015. doi: 10.1081/DDC-100102211.

DOUROUMIS, DD. et al. Development and Evaluation of Cetirizine $\mathrm{HCl}$ Taste-Masked Oral DisintegratingTablets. AAPS PharmSciTech, v.12, n.1, p.141-151, 2011. Available from: <http://dx.doi.org/10.1208/s12249010-9569-7>. Accessed: Aug. 10, 2015. doi: 10.1208/s12249-010-9569-7.

Guidance for Industry Orally Disintegrating Tablets. Food and Drug Administration, Center for Drug Evaluation and Research (CDER) Data Standards Manual 2008. Available from: <http:// www.fda.gov/downloads/Drugs/GuidanceComplianceRegulatory Information/Guidances/ucm070578.pdf>. Accessed: Jan. 10, 2015.
HIRANI, JJ. et al. Orally disintegrating tablets: A review. Tropical Journal of Pharmaceutical Research, v.8, n.2, p.161-172, 2009. Available from: <http://dx.doi.org/10.4314/tjpr.v8i2.44525>. Accessed: Jan. 10, 2015. doi: 10.4314/tjpr.v8i2.44525.

JIVRAJ, M. et al. An overview of the different excipients useful for the direct compression of tablets. Pharmaceutical Science and Technology Today, v.3, n.2, p.58-62, 2000. Available from: $<$ http://dx.doi.org/10.1016/S1461-5347(99)00237-0>. Accessed: Jan. 10, 2015. doi: 10.1016/S1461-5347(99)00237-0.

LERK, CF. et al. Effect of microcrystalline cellulose on liquid penetration in and disintegration of directly compressed tablets. Journal of Pharmaceutical Sciences, v.68, n.2, p.205-211, 1979. Available from: <http://dx.doi.org/10.1002/jps.2600680222>. Accessed: Jan. 10, 2015. doi: 10.1002/jps.2600680222.

OLMEZ, SS. et al. Formulation and evaluation of clozapine orally disintegrating tablets prepared by direct compression. Pharmazie, v.68, n.2, p.110-116, 2013. Available from: <http://ingentaconnect.com/content/govi/ pharmaz/2013/00000068/00000002/art00004>. Accessed:Jan. 10, 2015. doi: 10.1691/ph.2013.2098.

RAMTEKE, KH. et al. Veterinary Pharmaceutical Dosage Forms: A Technical Note. Austin Therapeutics, v.1, p.1-10, 2014. Available from: $<$ https://www.baidu.com/k?url=XyryWcvAqgUUFt66wTrJ6B EZ5vI0V6nKsps75Y6jAEO9j2LP9Yeisg0AnNrax18nw3GeShvVer HEyCYpdXgsGgLRfaxYQ5BYhP23n9DbZybAY_Ukm2I7UUZp3 nKiDQhfgeYqdNPesWvuMWVYYa_\&wd=\&eqid $=a c 15 b 5140002 \mathrm{f}$ 65d00000003568cbb0e>. Accessed: Jan. 10, 2015.

RAO, RN. et al. Development and validation of a liquid chromatographic method for determination of related-substances of mosapride citrate in bulk drugs and pharmaceuticals. Journal of Pharmaceutical and Biomedical Analysis, v.36, n.4, p.759-767, 2004. Available from: <http://www.sciencedirect.com/science/ article/pii/S0731708504003668>. Accessed: Jan. 10, 2015. doi: 10.1016/j.jpba.2004.08.004.

SWAMY, PV. et al. Orodispersible tablets of carbamazepine prepared by direct compression method using $3^{2}$ full factorial design. Dhaka University Journal of Pharmaceutical Sciences, v.7, n.1, p.1-5, 2008. Available from: <http://www.banglajol.info/ index.php/JPharma/article/view/1199>. Accessed: Jan. 3, 2016. doi:10.3329/dujps.v7i1.1199.

TSUKAMOTO, A. et al. Prokinetic Effect of the 5-HT4R Agonist Mosapride on Canine Gastric Motility. Journal of Veterinary Medical Science, v.73, n.12, p.1635-1637, 2011. Available from: $<\mathrm{http}: / /$ dx.doi.org/10.1292/jvms.11-0270>. Accessed: Jan. 10, 2015. doi: $10.1292 /$ jvms.11-0270.

TSUKAMOTO, A. et al. Effect of mosapride on prednisoloneinduced gastric mucosal injury and gastric-emptying disorder in dog. Journal of Veterinary Medical Science, v.74, n.9, p.1103-1108, 2012. Available from: <http://dx.doi. org/10.1292/jvms.12-0066>. Accessed: Jan. 10, 2015. doi: $10.1292 / \mathrm{jvms} .12-0066$.

WESTERMARCK, S. et al. Microcrystalline cellulose and its microstructure in pharmaceutical processing. European journal of pharmaceutics and biopharmaceutics, v.48, n.3, p.199206, 1999. Available from: <http://dx.doi.org/10.1016/S09396411(99)00051-X>. Accessed:Jan. 10, 2015. doi: 10.1016/ S0939-6411(99)00051-X. 